\title{
Perempuan Buruk Rupa dalam Sastra
}

\author{
Wahyu Heriyadi \\ STAI PUTRA GALUH \\ Jl. Raya Banjar KM 3 No. 141 \\ Cijantung, Kec. Ciamis, Kab. Ciamis, Jabar \\ Pos-el: wahyu.heriyadi@gmail.com
}

\begin{abstract}
Abstrak
Konsep kecantikan yang ditulis oleh pengarang perempuan kontemporer Indonesia saat ini mengalami perubahan: dari perempuan yang digambarkan cantik kepada perempuan buruk rupa. Melalui penelitian pada karya sastra kontemporer perempuan Indonesia: novel Saman (Ayu Utami, 1998) cerpen Mereka Bilang, Saya Monyet! (Djenar Maesa Ayu, 2002) cerpen/novel Wanita Berwajah Penyok (Ratih Kumala, 2006), dan novel/cerpen Si Manis dan Lelaki Ke Tujuh (Intan Paramaditha, 2010), penelitian kajian pustaka ini mencoba memahami pesan apa yang disampaikan oleh perempuan penulis mengenai perempuan buruk rupa. Berdasarkan kajian, terungkap bahwa pencitraan perempuan buruk rupa bukanlah tentang kelemahan perempuan melainkan tentang kekuatan, bahkan kekuasaan. Dengan demikian, kehadiran tokoh perempuan buruk rupa ini merupakan simbol perlawanan terhadap kemapanan ideologi kecantikan dan patriarki. Kata-kata kunci: perempuan buruk rupa, karya kastra, perempuan penulis Indonesia
\end{abstract}

\section{Ugly Women in Literature}

\begin{abstract}
The concept of beauty written by contemporary Indonesian female authors is changing: from women who are portrayed as beautiful to ugly. Through research on contemporary Indonesian women's literary works (novels and short stories): Saman (Ayu Utami, 1998) They Say, I'm Monkey! (Djenar Maesa Ayu, 2002) Woman with a Bender Face (Ratih Kumala, 2006), Si Manis and Seventh Man (Intan Paramaditha, 2010), the research undercovers messages conveyed by Indonesian women writers regarding to ugly women. Based on the study, it reveals that that the imaging of ugly women is not about female weakness, but it is about strength, and, even, power. Thus, the presence of the ugly female figure is a symbolic resistance towards the well establish concept of female beauty and patriachy.
\end{abstract}

Key words: Ugly Women, Literary Works, Indonesian Female Writers

\section{PENDAHULUAN}

Kecantikan merupakan kosakata yang memang diterapkan untuk perempuan. Perempuan selalu diharapkan untuk menjadi cantik, tampil cantik. Selain itu, kecantikan juga menjadi sebuah interpretasi sosial bagi keindahan. Dalam hal ini, budaya telah membentuk bagaimana keindahan itu adalah kecantikan. Dalam hal ini pula, seni pun seakan menjadi sebuah rentetan tentang keindahan. Begitu pun halnya dengan sastra, kita mesti berhadapan dengan kosakata konvensional tentang sastra dan keindahan. Lalu, apa sebenarnya cantik? Apa sebenarnya buruk? Apa saling keterkaitan antara keduanya? Cantik dan buruk, dua hal yang seakan saling melengkapi ini patut kita gugat, sampai sejauh mana batas-batas penafsiran dan penerjemahan mampu melakukan aksinya.

Konstruksi kecantikan setidaknya telah membentuk ideologi dalam tatanan masyarakat. Ideologi kecantikan merupakan permasalahan dari klasik hingga kontemporer bagi perempuan. Tak dapat dipungkiri bahwa konstruksi budaya akan mengunggulkan kecantikan, dan melipat keburukan ke dalam tempat yang tersembunyi. Sebagai dua sisi mata uang yang bertentangan, kecantikan dan keburukan saling bersitegang.

Memang sistem kecantikan di dalam masyarakat tentunya akan berlainan. Jika menurut Ayu Utami dalam kumpulan 
esainya Si Parasit Lajang (2003), bahwa perempuan Asia berkeinginan untuk menjadi putih, ini terbukti dengan lakunya produk kosmetika untuk memutihkan kulit. Sedangkan perempuan Eropa dan Amerika ternyata sangat berkeinginan untuk berkulit coklat dan agak gelap, karena kulit coklat dan agak gelap mengandung prestise sosial. Hal yang menunjukkan perempuan Eropa dan Amerika telah mengunjungi Asia, berjemur, menikmati cuaca tropis. Hal ini menekankan bahwa untuk mengakses kecantikan, dibutuhkan sebuah stratifikasi sosial di dalam masyarakat.

Bagaimana kemunculan tokoh perempuan yang buruk rupa di dalam sastra kontemporer? Ini tentunya akan sangat menarik untuk dibahas. Tulisan ini akan memperlihatkan bagaimana permasalahan akutnya kecantikan ditampilkan dalam gugatan melalui teks sastra melalui karakter perempuan buruk rupa.

\section{TEORI}

Cantik menurut Kamus Besar Bahasa Indonesia (KBBI) adalah elok, molek. Terlihat bahwa cantik, kecantikan ditujukan kepada perempuan. Sedangkan buruk, berdasarkan KBBI yang ditujukan kepada wajah, berarti tidak cantik, tidak elok, jelek. Dapat kita lihat, bahwa buruk dalam arti wajah pun dialamatkan kepada perempuan. Dalam rangkaian oposisi biner, buruk tentunya tidak dikehendaki ada di tengah masyarakat. Kecantikan adalah sebuah tatanan ideal.

Sementara itu, Patrizia Betella dalam The Ugly Women (2005) menyatakan bahwa:

Karen A. Callaghan has pointed out that beauty norms play an integral role in the construction of gender identity in a patriarchal system. Rules of beauty 'serve as a locus of control over the most fundamental aspects of identity - the selft, the body, and intersubjectivity'. Women who do not conform to standards of beauty are considered deviant; more over, feminine beauty is defined primarly for men's pleasure. Beauty standards are part of cultural discourse regarding age, class, race. The ugly woman, by not confirming to the norms of beauty, is depicted as anomalous, rebellious, and transgressive. Such a feminine type escapes control and chalanges social order. Since she may cause the wild, unrestrained, and chaotic to emerge, she is excluded and punished.

Disebutkan dalam kutipan tersebut bahwa norma-norma kecantikan memainkan peran integral dalam membangun identitas gender dalam sistem patriarki. Aturan kecantikan berfungsi sebagai pusat kendali atas aspek identitas yang paling mendasar, diri, tubuh, dan intersubjektivitas. Wanita yang tidak cantik dianggap menyimpang dari norma. Kecantikan perempuan didefinisikan sebagai kesenangan laki-laki dan standar kecantikan itu menjadi bagian dari wacana budaya mengenai usia, kelas, dan ras. Wanita jelek adalah anomali dan pemberontak serta transgresif. Tipe ini menentang tatanan sosial sehingga menyebabkan alam liar, tidak terkendali dan memunculkan kekacauan, oleh karena itu ahrus dihukum dan diasingkan.

Beberapa karya sastra yang ditulis perempuan yang dipilih dalam tulisan ini menggugat kemapanan ideologi kecantikan. Sebuah ideologi kecantikan yang ditopang dan diagitasikan oleh kapitalisme. Mitos tentang kecantikan telah dibentuk oleh segelintir orang, kemudian direpresentasikan melalui media, seperti iklan, film, televisi, bahkan sastra sendiri.

Sastra dalam hal melakukan perlawanan terhadap ideologi kecantikan, mesti berhadapan dengan ketidaksadaran dan alam bawah sadar dari kecantikan. Kecantikan telah terbangun sedemikian rupa hingga ke dalam alam bawah sadar yang subtil. Di tataran inilah sastra hendak masuk, ke alam bawah sadar menghadirkan sebuah perempuan buruk rupa.

Charlotte M. Wright dalam Plain and Ugly Janes (2000), menyatakan bahwa 
standar untuk karakter perempuan buruk rupa adalah tidak dapat kita memberikan batasannya.

The "standard ugliness" by which female characters are judged cannot be limited to only those for whom the authors actually use the word "ugly." To do so would eliminate many caharcters who are clearly meant to be seen as physically undesirable within the context of their stories. Instead, it is necessary to include all the degrees of non beauty: from the "nearly pretty," the "plain" and the "homely," to the "ugly," the "hideous," the "repulsive," and even the "deformed."

Perilaku tokohnya pun bermacammacam, tidak ada konvensi di dalamnya, karena bertujuan untuk memecah dan mengganggu konvensi yang ada tentang kecantikan. Melalui hal inilah kemudian ditawarkan sebuah konsep tentang estetika buruk rupa melalui sastra.

Penelitian mengenai perempuan dan sastra sudah sangat berkembang di Indonesia. Salah satu figur perempuan dalam karya sastra tersebut membahas sisi kecantikan perempuan. Penelitian yang dilakukan Kurnianto (2014), misalnya mengkaji kecantikan perempuan melalui tiga cerpen karya Paramaditha: (1) Misteri Polaroid, (2) Darah, dan (3) Perempuan Tanpa Ibu Jari. Hasilnya, Kurnianto (2014) berpendapat bahwa:

Perempuan tidak mempunyai kuasa atas dirinya sendiri sehingga konstruksi partirarki atas cantik dan tidak cantik membuat perempuan menjadi liyan, dalam konstruksi tersebut perempuan justru ikut serta me-liyan-kan perempuan.

Melalui penelitian Kurnianto (2014) ini kita dapat melihat bahwa, ada istilah cantik dan tidak cantik. Sehingga istilah tidak cantik sebagai antitesis dari cantik, tidak lain sebagai istilah yang dekat dengan buruk rupa. Sehingga melalui penelitian tersebut, kita dapat melihat cantik maupun buruk bagi seorang perempuan ternyata tidak mempunyai kuasa atas dirinya sendiri.

Sementara ini, kajian mengenai sosok perempuan buruk rupa dalam sastra Indonesia masih jarang ditemukan. Penelusuran dengan mesin pencari seperti Google pun tidak menampakkan hasilnya. Akan tetapi, apabila kita mencari hasil penelitian tentang perempuan buruk rupa dalam bahasa Inggris melalui kata kunci mengenai Ugly in Literature, maka kita akan mendapatkan beberapa penelitian. Salah satunya ialah penelitian yang dilakukan oleh Chinchilla (2012).

Berdasarkan kajiannya, Chinchilla (2012) menyatakan bahwa keburukan seharusnya ditempatkan secara terpisah dari kecantikan, karena selama ini keburukan menjadi kategori kedua setelah kecantikan. Chinchilla (2012) menyebutkan:

Bahwa perkembangan sejarah yang pernah menorehkan setiap tulisan tentang konsep baik itu, maka secara langsung ataupun tidak langsung juga terkait dengan keburukan. Hal ini kemudian secara perlahan akan membangun estetika keburukan yang menjadikannya semakin konsep keburukan yang mandiri dari konsep kecantikan.

Chinchilla (2012) berargumen bahwa keburukan sangat esensial di dalam kesusastraan karena melalui figur tersebut dunia fiksi menjadi lebih kompleks. Selain itu, penulis fiksi dituntut memiliki keahlian untuk membangun karakter yang buruk rupa di dalam karyanya.

Selain penelitian Kurnianto dan Chincilia tersebut, ada kajian terhadap novel Saman karya Ayu Utami yang dilakukan oleh Katrin Bandel (2006). Dalam kajian tersebut dibahas tokoh Upi sebagai representasi seksual yang cukup penting yang dihadirkan di dalam novel tersebut, Upi hadir dengan perilaku seksual yang tidak terkekang karena kecatatan mentalnya.

Penelitian selanjutnya adalah yang dilakukan oleh Bramantio (2010) yang membahas empat cerpen dalam kumpulan 
cerpen Sihir Perempuan karya Intan Paramaditha. Cerpen-cerpen tersebut adalah: Sang Ratu, Misteri Polaroid, Pemintal Kegelapan, dan Perempuan Buta Tanpa Ibu Jari. Pada kumpulan cerpen tersebut, pembahasannya adalah untuk memunculkan sisi yang berbeda dari karya perempuan penulis lainnya, Bramantio (2010) menyebutnya dengan menghadirkan sisi kelam dunia perempuan. Sisi kelam dunia perempuan, tentu tidak menghadirkan keindahan dan kecantikan, sisi kelam merupakan antitesis dari kecantikan.

Berdasarkan penelusuran penelitian terdahulu, sudah mulai adanya upaya untuk masuk ke dalam kajian konsep buruk rupa di dalam sastra. Meski demikian, seperti yang telah dibahas oleh Chinchilla (2012), konsep buruk rupa di dalam sastra Indonesia itu ternyata masih menempel di dalam konsep kecantikan di dalam sastra. Oleh karena itu, tulisan ini adalah salah satu upaya untuk mengkaji lebih khusus dan mandiri mengenai perempuan buruk rupa di dalam sastra yang ditulis oleh perempuan penulis, sehingga dapat memberikan gambaran bagaimana perempuan itu sendiri di dalam karya sastranya menampilkan konsep buruk rupa.

\section{METODE}

Metode di dalam penelitian ini adalah studi pustaka. Sumber data dalam penelitian ini berupa cerpen dan novel karya perempuan penulis Indonesia, penulis tersebut dibatasi pada tema yang dihadirkan yaitu perempuan buruk rupa, sehingga kemudian dapat terlihat melalui novel Saman karya Ayu Utami, cerpen Mereka Bilang, Saya Monyet! karya Djenar Maesa Ayu, Wanita Berwajah Penyok karya Ratih Kumala, dan Si Manis dan Lelaki Ketujuh karya Intan Paramaditha.

Data dari cerpen dan novel tersebut dianalisis berdasarkan konsep buruk rupa sebagai perlawanan terhadap konsep kecantikan, hasil penelitian ini kemudian disajikan secara kualitatif.

\section{HASIL DAN PEMBAHASAN \\ AYU UTAMI, SAMAN (1998).}

Upi memang bukan tokoh utama seperti halnya Wis yang merubah namanya menjadi Saman, juga tokoh Laila yang dihadirkan begitu memikat dan banyak diulas dalam kajian sastra Indonesia. Tetapi kehadiran Upi di dalam novel ini, seakan menguak dan menghadirkan wacana perempuan buruk rupa dan disabilitas. Upi adalah tokoh yang juga penting dalam novel ini, wacana yang dihadirkan melalui Upi ini pun memiliki kompleksitas dalam relasi sosiopolitik.

Nama gadis itu Upi. Kemudian si ibu bercerita tentang anak perempuannya yang gila. Ketika lahi, kepalanya begitu kecil sehingga ayahnya menyesal telah membunuh seekor penyu di dekat tasik ketika istrinya hamil muda. Dan anak itu akhirnya tak pernah bisa bicara, meski kemudian tubuhnya tumbuh dewasa. Barangkali karena dia tidak menguasai bahasa manusia maka setan mengajaknya bercakap-cakap. Di usia remaja ia mulai kesambet dan menjadi beringas. Semula, ketika orang-orang menyadap karet, dia malah suka merancap dengan pohon-pohon itu, menggosokgosok selangkangannya, untungnya tanpa membuka celana. Orang-orang menonton-laki-laki merasa asyik dan perempuan-perempuan menjadi malu-tapi kami tetap memelihara dia. Namun setan pun terus memelihara dia. Lama-kelamaan, ia juga tertarik pada binatang-binatang, terutama kambing. Setiap kali, ia juga menganiaya hewan-hewan itu, kadang sampai mati. Karena ia juga memperkosa dan menyiksa ternak tetangga, kami terpaksa memasungnya. Semula dengan balok kayu yang mengapit pergelangan kakinya. Tetapi karena itu membuat dia tak bisa beranjak dan menderita, kami membangun bilik kecil ini dan mengunci dia di dalam. Setan agaknya menyukai darah haid. Ia biasanya 
menjadi ganas seminggu menjelang darah kotor itu datang. Jika kelihatan tabiatnya membaik, biasanya seminggu setelah selesai haid, kami melepasnya. Ketika bebas, ia suka berkelana ke dusun dan kota lain. Kami biarkan saja, sebab dari sana tak ada laporan bahwa ia mengganngu. Tapi suatu kali ia kumat tanpa terduga. Di dapur, ia mengempit seekor bebek di pangkal pahanya sambil mencekik leher binatang itu. Anson, abangnya, memarahinya dan mencoba menyelamatkan bebek itu. Tetapi Upi mengambil asam sulfit untuk mengencerkan karet, dan menyiramkan ke wajah kakaknya sendiri sehingga rusak dan buta matanya yang kiri. Gadis itu amat berbahaya. Kami khawatir kelak ia membikin celaka orang lagi. Karena itu kami mengurung dia. Kemarin dulu ia berhasil memutus rantai yang telah berkarat dan kabur. (71-72)

Dalam novel ini pun digambarkan mitos terhadap perempuan yang terlahir dengan disabilitas berkembang di dalam masyarakat. Kelahiran Upi dikaitkan dengan sebuah tindakan yang dilakukan terpisah, dari perbuatan ayahnya yang membunuh penyu ketika istrinya hamil muda. Premis-premis terpisah ini dijadikan seakan berkaitan sehinga berdampak kepada kesimpulan bahwa kepala Upi begitu kecil.

Seperti apa sebenarnya Upi ini di dalam kategori orang dengan disabilitas? Kemungkinan yang mendekati, Upi adalah orang dengan disabilitas intelektual. Upi digambarkan memiliki "kepala kecil." Upi sebenarnya adalah gambaran sebuah kebebasan, meski dipandang sebagai sebuah pengecualian atau "yang lain" dalam tatanan masyarakat. Kita dapat melihat bagaimana bebasnya Upi dan apa yang dilakukannya menjadi pusat perhatian bagi masyarakat sekitar melalui aksi-aksi yang dihadirkannya, melalui perjalananperjalanan kesendiriannya menyusuri kampung-kampung.
Pemasungan merupakan sebuah hukuman, yang dijatuhkan dari orang terdekat yang memiliki wacana atribut kenormalan terhadap orang dengan disabilitas. Ini juga berlaku terhadap Upi. Tanpa daya, keluarganya pun melakukan pembenaran dengan adanya pemasungan Upi.

\section{DJENAR MAESA AYU, MEREKA BILANG, SAYA MONYET! (2002).}

Mereka Bilang Aku Monyet seakan menjaga sebuah moralitas dalam diri tokohnya, pembenturan moral dilakukan terhadap tokoh di sekelilingnya. Ada sebuah perdebatan identitas, tokohtokohnya dihadirkan melalui perpaduan sifat-sifat binatang. Setiap tokoh memiliki banyak karakter binatang, penanda bahwa sifat binatang tidak hanya satu saja yang bisa ditempelkan kepada manusia. Manusia bisa memiliki beragam karakter binatang.

Saya berkaki dua, berkepala manusia, tapi menurut mereka saya adalah seekor binatang. Kata mereka saya adalah seekor monyet. Waktu mereka mengatakan itu kepada saya, saya sangat gembira. Saya katakan, jika saya seekor monyet maka saya satu-satunya binatang yang paling mendekati manusia. Berarti derajat saya berada di atas mereka. Tapi mereka bersikeras bahwa mereka manusia bukan binatang, karena mereka punya akal dan perasaan. Dan saya hanyalah seekor binatang. Hanya seekor monyet! (hal 3)

Tokoh yang selalu dilekatkan dengan karakter monyet, selalu dihinggapi kegelisahan akan identitasnya. Keberadaannya seakan dipinggirkan oleh relasi tokoh-tokoh yang ada karena tokoh ini adalah monyet. Sementara itu, tokoh sendiri menyadari bahwa dirinya adalah monyet, namun ternyata ia memiliki sebuah penafsiran identitas yang dimunculkan untuk menggugat keberadaan dirinya.

Kemunafikan dimunculkan di sanasini digambarkan melalui tokoh-tokohnya. Privasi dari tokoh-tokohnya tidak dikendaki 
untuk ditebarkan ke khalayak, sebab kemunafikan telah melanda. Di sisi inilah moralitas sementara dibangun, sedangkan keberadaan pengusung moralitas ini ternyata dijaga oleh segelintir kemunafikan.

Tokoh yang dilekatkan dengan monyet ini merasa telah merdeka setelah melakukan serangan balasan terhadap tokoh lainnya yang telah menyerang dan berlindung pada moralitas tetapi munafik. Ia memberikan pesan, setidaknya kemunafikan itu mesti dilawan. Tokoh yang buruk rupa dan dipinggirkan karena dilabelkan sebagai monyet ini menggugat dan melakukan balasan.

\section{RATIH KUMALA, WANITA BERWAJAH PENYOK (LARUTAN SENJA, 2006).}

Interaksi tokoh perempuan penyok adalah dikecualikan dan disingkirkan dari lingkungannya. Pemasungan terhadapnya adalah proses peminggiran dan penghukuman akibat dari keberadaannya. Perempuan penyok ini dianggap tidak ada, karena dianggap mengganggu sebuah pola masyarakat yang terlenakan oleh kecantikan dan kewajaran.

Konon dia lahir tanpa diminta. Korban gagal gugur kandung dari seorang perempuan. Hasil sebuah hubungan gelap yang dilaknat warga dan Tuhan. Perempuan yang saat ini disebut ibunya bukanlah ibu yang sebenarnya. Dia hanya inang yang berkasihan lalu bergantian menyusui lapar mulut dua orang bayi; bayinya sendiri dan bayi berwajah penyok yang dibuang orang di pinggir kampung. (hal 90)

Dapat dilihat bahwa kelahiran tokoh dalam cerita ini pun bahkan tidak diakui asal-usulnya. Ini seakan mencoba untuk menghapus biografi dalam diri perempuan berwajah penyok. Keluarga yang menjadi tempatnya bernaung adalah bukan keluarga sebenarnya, hanya didasarkan pada belah kasihan semata.

Ia seakan menjadi sebuah bahan cemoohan dan penyiksaan. Namun, ketika ia melawan, dengan ramainya ia mesti disalahkan. Di titik itulah ia menjadi sebuah kesalahan yang terjadi di dalam masyarakat. Ketika ia melakukan sebuah pembelaan diri, perbuatannya pun adalah sebuah kesalahan. Tidak ada alasan pembenaran baginya.

Dalam kesendirian di pasungannya, ternyata ia telah membaca dan akrab dengan alam, di dalam cerita tersebut adalah bulan, berinteraksi penuh penghayatan dan bersetia. Entah mengapa dengan bulan, apa mungkin karena bulan merupakan keindahan di dalam kegelapan? Sehingga ada perasaan senasib secara simbolik? Ada perasaan relasi kesejajaran antara dirinya dengan bulan. Bahwa bulan adalah dirinya, bahwa pantulan cahaya yang gelap dalam dirinya sedikit memberkas dalam kegelapan itu sendiri.

Hingga akhir hayatnya, ia mesti berada dalam pasungan. Sebuah penjara dan pengekangan dari masyarakat terhadap keberadaannya dan reaksi terhadap perlawanan yang dilancarkannya.

\section{INTAN PARAMADITHA, SI MANIS DAN LELAKI KE TUJUH (KUMPULAN BUDAK SETAN, 2010).}

Keburuk rupaan dalam tokoh Ariah, dapat disandingan dengan dongengdongeng tentang kecantikan dari sastra Eropa hingga Si Manis Jembatan Ancol. Interaksi tokoh lelaki dan perempuan buruk di dalam cerpen Si Manis dan Lelaki Ketujuh ini adalah sebuah relasi yang timpang, perempuan buruk di kisah ini memperbudak lelaki.

Relasi seperti ini sengaja dihadirkan untuk menggugat dominasi dari maskulinitas. Terlebih lagi dengan ditundukkannya lelaki oleh perempuan buruk rupa, seperti halnya melalui tokoh Ariah. Ini tentunya akan sangat mengganggu kenyamanan dari keindahan dan ketertundukkan perempuan terhadap lelaki.

Wajah perempuan itu rusak. Hidung dan pipinya sulit dibedakan, tertutup gumpalan daging tak rata, kasar. 
Mata kirinya bengkak, merah seperti bisul meradang. Tanpa rambut lurusnya aku tak yakin ia mirip manusia. Ia serupa tumor besar, menggelembung, carut marut. (hal 93)

Ariah dianggap memiliki kekuasaan terhadap lelaki yang memiliki keterbatasan secara finansial, dan akhirnya bangkrut. Di ranah inilah, kuasa dari Ariah bermainmain. Hal yang diinginkan oleh Ariah adalah kenikmatan seksualitas sekaligus menguasai. Lelaki dihadirkan dalam gambaran tidak menikmati tetapi sekaligus merasakan kenikmatan yang disuguhkannya. Sebuah kenikmatan dari estetika buruk rupa yang ditawarkan. Ariah pun menjadi semakin misterius dengan keburukrupaannya. Perempuan tersebut meninggalkan kecantikannya denganmenghancurkan kecantikannya, dan memulai lagi sesuatu dengan keburukrupaan. Keburukrupaan dijadikan sebuah ajang yang eksotik sekaligus mendebarkan. Menggemparkan. Merusak tatanan ideologi kecantikan yang mapan.

\section{PENUTUP}

Melalui kehadiran perempuan buruk rupa dalam sastra, kita dapat melihat bagaimana strategi perempuan penulis melakukan perlawanan melalui wacana buruk rupa kepada ideologi kecantikan yang mapan melalui ragam teknik penulisan dan penceritaan yang dihadirkannya. Perempuan buruk rupa ini memiliki banyak potensi untuk dikisahkan, sebab belum terlalu banyak disentuhkan ke dalam karya sastra, bahkan pada penelaahannya. Pengarang perempuan dalam tulisan ini tidak lagi menitikberatkan karya mereka pada pandangan tradisional seperti halnya kisah dari "itik yang buruk rupa" kemudian menjadi "angsa yang cantik." dan tidak lagi-lagi melakukan pengulangan ke arah itu, melainkan menghadirkan sesuatu yang benar-benar berkebalikan dengan yang ada.

Beberapa hal yang dapat kita tangkap melalui tulisan perempuan pengarang ini di antaranya mereka melukiskan realitas yang begitu adanya terjadi ketika perempuan buruk rupa yang dihadirkan dalam teks sastra telah dikalahkan, atau memberikan perlawanan yang simbolis melalui karakter tokoh perempuan buruk rupanya terhadap kemapanan ideologi kecantikan dan budaya patriarki.

\section{DAFTAR PUSTAKA}

Ayu Utami. 1998. Saman. Jakarta: Kepustakaan Populer Gramedia.

Ayu Utami. 2003. Si Parasit Lajang: Seks, Sketsa \& Cerita. Jakarta: Gagas Media.

Bramantio. Suara-suara Perempuan yang Terbungkam dalam Sihir Perempuan. Bramantio, dkk. 2010. Dari Zaman Citra Ke Metafiksi: Bunga Rampai Telaah Sastra DKJ. Jakarta: Kepustakaan Populer Gramedia.

Charlotte M. Wright. 2000. Plain and Ugly Janes: The Rise of the Ugly Woman in Contemporary American Fiction. Iowa City: University of Iowa Press.

Djenar Maesa Ayu. 2002. Mereka Bilang Saya Monyet! Jakarta: Gramedia.

Ery Agus Kurnianto. Representasi Tubuh dan Kecantikan dalam Tiga Cerpen Intan Paramaditha: Sebagai Sebuah Tatanan Simbolik dalam Dunia Perempuan. METASASTRA, Vol. 7 No. 1, Juni 2014: 23-34.

Intan Paramaditha, dkk. 2010. Kumpulan Budak Setan. Jakarta: Gramedia.

Katrin Bandel. 2006. Sastra, Perempuan, Seks. Yogyakarta: Jalasutra.

KBBI Daring. 2016. Kamus Besar Bahasa Indonesia. https://kbbi.kemdikbud.go.id/ diakses 28 Agustus 2018. 
Telaga Bahasa Vol 7 No 1 Juni 2019: 109-116

Oscar Delgado Chinchilla, 2012. Towards a Better Understanding of the Ugly in Literature. Revista de Lenguas Modernas No. 17, 2012 p 323-338.

Patrizia Betella. 2005. The Ugly Women: Transgressive Aesthetic Models in Italian Poetry from the Middle Ages to the Baroque. Canada: University of Toronto.

Ratih Kumala. 2006. Larutan Senja. Jakarta: Gramedia. 